\title{
Influence of Organic Amendments on Growth and Lead Uptake of Spinach (Spinacia oleracea L.) Grown in Lead-Contaminated Soil
}

\author{
Abdur Rashid ${ }^{1,2 *}$, Tayyaba Naz ${ }^{1}$, Muhammad Mazhar Iqbal ${ }^{1,3}$, Javed Akhtar ${ }^{1}$, Muhammad Saqib ${ }^{1}$, Hafiz Muhammad \\ Anwar-ul-Haq ${ }^{1}$, Rooh Ullah ${ }^{2}$, Salahudin Kabir ${ }^{4}$, Qiyamud Din Ikram ${ }^{5}$ \\ ${ }^{1}$ Institute of Soil and Environmental Sciences, University of Agriculture Faisalabad, Punjab 38000, Pakistan \\ ${ }^{2}$ Ministry of Rural Rehabilitation and Development, Kabul, Afghanistan \\ ${ }^{3}$ Soil and Water Testing laboratory Chiniot, Department of Agriculture, Government of Punjab, Lahore, Pakistan \\ ${ }^{4}$ Institut Supérieur d'Agriculture de Lille, Lille 59800, France \\ ${ }^{5}$ United Nation University, Institute for Environment and Human Security Bonn, Bonn 53113, Germany
}

Corresponding Author Email: abdurrashiduaf@gmail.com

https://doi.org/10.18280/eesrj.070201

Received: 19 February 2020

Accepted: 13 May 2020

\section{Keywords:}

biochar, compost, heavy metal pollution, immobilization, Spinacia oleracea $L$

\begin{abstract}
Lead $(\mathrm{Pb})$ is a very serious contaminant in soil because of its widespread application in agricultural, residential and industrial environments and it has ultimately harmful impacts on plant and human health. Organic amendments such as biochar (BC) and compost may reduce heavy metal toxicity in a plant. The main focus of the present research work was to evaluate the synergistic use of $\mathrm{BC}$ and compost to enhance the growth of spinach and to reduce the $\mathrm{Pb}$ uptake in spinach (Spinach oleracea $\mathrm{L}$.) grown on $\mathrm{Pb}$-contaminated soil. The results showed that $\mathrm{Pb}$ toxicity at its higher-level (1000 mg Pb kg-1 soil) reduced the growth, photosynthetic pigments and physiological attributes in 45-days-old spinach. However, this decrease was less pronounced in BC and compost amended soil. The BC and compost application enhanced shoot dry weight, total chlorophyll contents, membrane stability index and relative water contents at both applied rates 500 and 1000 $\mathrm{mg} \mathrm{kg}-1$ of $\mathrm{Pb}$ in soil. Under low Pb-stress (500 mg Pb kg-1), BC and compost application increased the shoot dry weight (33.5 and 39.7\%), chlorophyll contents (21 and 22.1\%), membrane stability index (18.8 and 17\%) and relative water contents (44 and 34.6\%). While at high $\mathrm{Pb}$-stress (1000 mg kg-1) BC and compost increased the shoot dry biomass ( 17.8 and $33.3 \%$ ), chlorophyll contents ( 31.3 and $32.5 \%)$, membrane stability (27.1 and $23.5 \%$ ) and relative water contents (37 and 32.9\%) respectively. Moreover, under low $\mathrm{Pb}$ stress the application of $\mathrm{BC}$ and compost reduced the $\mathrm{Pb}$ uptake in spinach by 78 and $56 \%$. While under high $\mathrm{Pb}$ stress, $\mathrm{BC}$ and compost reduced the $\mathrm{Pb}$ uptake by 69 and $52 \%$ respectively. Therefore, it can be concluded that organic amendments can ameliorate $\mathrm{Pb}$ toxic effects in spinach by changing the physiological attributes (total chlorophyll content, MSI and RWC) under Pb stress. Among the tested amendments, applied BC proved more effective for reducing $\mathrm{Pb}$ toxicity in spinach.
\end{abstract}

\section{INTRODUCTION}

Heavy metal pollution of soil is a threatening issue around the globe. It is not only responsible to affect the quality and yield of crops, human and animal health but also the environment [1]. The major sources of heavy metal pollution in soil can be find in sewage sludge, industrial waste, mining, excessive pesticides and chemical fertilizers use and smelting of ores [2]. These sources have caused a recent gradual increase in heavy metal concentration and are swept over the self-purification ability of nature [3]. Subsequently, these heavy metals persist for a long period, which can be up-taken by plants to accumulate in plant tissues and hence enter to food chain [4]. These trace elements are entering to living bodies via different means like air, food, water and skin contact. Major health problems linked with heavy metals are mild cognitive impairment (MCI), chronic anemia and cardiovascular diseases [5], damage of nervous system, kidney, brain [6], bones, teeth, skin [7]). Some of these trace elements are carcinogenic, endocrine disruptors, teratogenic and mutagenic whereas, others can cause behavioral and neurological disorders especially in children [8]. These trace elements at a high concentration are obstructing both growths of underground and above surface parts of plants which can cause to inhibit the development and growth of plants and also to disturb many physiological and biochemical activities e.g. reduction in transpiration rate, damage the photosynthetic apparatus, cause breakdown synthesis, injury of the cell membrane, increase lipid peroxidation and also affect several enzymes [9].

Among heavy metals, $\mathrm{Pb}$ is considering one of the most hazardous toxic elements and thus it is biologically nonessential in nature. Lead occurs extensively in the environment due to its wide spread applications in petrol, paints, explosive materials, industrial wastes, and sludge. Uptake and translocation of $\mathrm{Pb}$ occur in plants which causes toxic impacts on its health and ultimately a declination occurs in the plant biomass production. Usually, plant avoids its toxic effects by adopting different cellular mechanisms such as adsorption to the cell wall, vacuole compartmentalization, increase the 
active flux, or inducing of the metal chelates [10]. Lead is neurological and physiological toxic to human beings, severe poisoning $\mathrm{Pb}$ can result in disabilities of kidney, liver, brain and reproductive system, resulting severe diseases or death [11]. For instance, Cheng and $\mathrm{Hu}$ have shown that poisoning effects of $\mathrm{Pb}$ are the blood pressure, kidney, peripheral and central nervous systems [12]. An excessive amount of $\mathrm{Pb}$ in the soil can decline productivity of soil and a little amount of $\mathrm{Pb}$ can alter some dynamic processes of the plant such as mitosis, photosynthesis and water adsorption with poisonous signs of stunting foliage, leaves wilting, dark green and brown short leaves [13]. Lead is released into the aquatic and terrestrial ecosystems and ultimately turns out to be the part of food-chain and can cause serious consequences to living entities $[14,15]$. Lead has teratogenic and mutagenic causing hazardous effects to various biological systems viz. cancer, reproductive system damage, neurodegenerative impairment and renal failure [16]. Therefore, taking into consideration the hazardous effects of $\mathrm{Pb}$, the World Health Organization (WHO) set a permissible limit $10 \mu \mathrm{gL}^{-1}$ for $\mathrm{Pb}$ in potable water [17]. Pakistan's environment has been polluted terribly and considerable efforts are required in order to handle these environmental pollutants. Therefore, there is need to adopt cost-effective and eco-friendly approaches for these heavy metal's remediation. A lot of approaches are available for remediation of these hazardous toxic compounds such as reverse osmosis, ion exchange, and chemical reduction. However, these techniques are not cost-effective and they can also reduce soil fertility.

Food security is a multidimensional approach which covers enough, safe, and nutritious quality of the food. Worldwide struggles are being made of coping with global diet demands by producing safe and enough food [18]. Agriculture land adulteration by pesticides accumulation, wastewater irrigation, and atmospheric deposition etc. transfer the toxin to foodchain, that can be mitigated by using various soil amendments. Numerous amendments using to solve this issue of the polluted soil up to some extent, hence it can help to meet the food security targets [19]. Significant efforts around the globe have been made for remediation of contaminated soil as shown in the increasing of current literature evidence of soil amendments [20, 21]. Remediation technologies of contaminated soil and wastes based on transportation, landfilling and excavation which are too much effective at lowering risk but it might be highly costly to implement [22]. Similarly, some in-situ techniques of Chemical/physical or bioremediations are using for polluted soils management [23] [24]. Innovative low-input and low-cost soil remediation technologies are required for community acceptance. In-situ stabilization of heavy metal by the addition of numerous types of organic amendments is one of the promising contaminated soil remediation technology [25]. It's well-known that organic amendments application to contaminated soil can immobilize metalloids and heavy metals by forming stable complexes or adsorption reactions [26]. Biochar is a solid carbon-rich material which is produced through pyrolysis of organic matters under complete or partial elimination of oxygen at high temperature [27]. Biochar is possibly unique solution for remediation of polluted soils, the microporous structure of BC result in activation of functional groups and high surface area that highly affecting the holding behavior of the trace elements [28]. As an amendment to soil often BC has a liming effect and offers a reactive surface to interact with heavy metals [29] [30]. Biochar applications to contaminated soil also improves the chemical, physical and biological properties of the soil [31]. Addition of biochar to contaminated soil produced negative charges and thus, the cation exchange capacity (CEC) is increasing due to higher $\mathrm{pH}$ induction. It turns to the electrostatic attraction within soil particles and heavy metals cations, the binding attraction will become stronger [32]. Similarly, compost amendments also improve the growth of the crop and reduce the bioavailability of $\mathrm{Pb}$ sorption in soil for living entities [33]. High metals biding abilities of compost attribute to a high fulvic and humic acid concentration of composts [34]. Spinach is one of the most valuable green vegetables, with numerous health benefits and packed of essential nutrients [35]. It has been cultivated widely across the world. The modern nutritionists recommended the spinach as the best source of vitamins, iron and minerals [36]. Such minerals i.e. $\mathrm{Mg}, \mathrm{Na}, \mathrm{K}, \mathrm{P}, \mathrm{Ca}, \mathrm{Cu}, \mathrm{I}, \mathrm{Zn}$ and $\mathrm{Fe}$; it also has folic acid and vitamins A, E, K, C and B complex; spinach is very rich in amino acids and fiber. Spinach benefits including its soothing, diuretic, calming, demulcent, cooling, laxative, detoxifying and other properties. This leafy vegetable can be used for preparing a variety of meals, as well as for tincture, infusion, or very therapeutic spinach juice [37]. The main focus, of the present work was to evaluate the synergistic use of biochar and compost to enhance the growth of spinach and to reduce the $\mathrm{Pb}$-uptake in spinach crop.

\section{MATERIALS AND METHODS}

\subsection{Experimental layout}

A pot experiment was conducted in the wire house, Institute of Soil and Environmental Sciences, University of Agriculture, Faisalabad, using completely randomized factorial design with 3 replicates for each designed treatment. There were two treatment factors: organic amendments (i.e., Bermuda grass biochar $1 \%$ and poultry manure compost $1 \% \mathrm{w} / \mathrm{w})$, and applied rate of 0,500 and $1000 \mathrm{mg} \mathrm{Pb} \mathrm{kg}^{-1}$ soil using $\mathrm{PbNO}_{3}$ as a source. The spinach seeds were sown in the glazed pots, each filled with $10 \mathrm{~kg}$ soil and respective treatments (organic amendments and $\mathrm{Pb}$ ). After one week of germination, thinning was done, and 10 plants were kept in each pot. The plants were periodically irrigated with tap water $\left(\mathrm{EC}=0.5 \mathrm{dSm}^{-1}\right)$, to maintain $60 \%$ water holding capacity of soil following the formulae as reported by Abu-Hamdeh [38].

$$
=\frac{\begin{array}{c}
\text { Waterholding capacity, } \% \\
\text { Weight of saturated soil-oven dry weight of soil }
\end{array}}{\text { Oven dry weight of soil }} \times
$$

\subsection{Agronomical and physiological traits}

Shoots and roots fresh and dry weights were measured after 45 days of germination. The plants were separated into shoots and roots, rinsed with distilled water, and oven dried in a forced-draft oven at $65 \pm 5^{\circ} \mathrm{C}$ for about 72 hours and reweighting.

Leaf chlorophyll index (SPAD-value) was determined using a portable SPAD-502 (Minolta, Osaka, Japan) following [39]. Three fully expanded leaves of spinach are selected in each pot, and average SPAD readings were recorded (from the leaf tip to the leaf base) at 10:00 to 11:00 am. The measurement was recorded at 45 days after seed germination. 
The membrane stability index (MSI) of intact plant, was determined according to the method of Sairam [40], Leaf discs of $0.1 \mathrm{~g}$ was taken in $10 \mathrm{ml}$ of double distilled water in 2 sets. One set was kept in water bath at $40^{\circ} \mathrm{C}$ for $30 \mathrm{~min}$ and the electrical conductivity was recorded by electrical conductivity meter (EC1). Second set was kept in the same water bath at $100^{\circ} \mathrm{C}$ for $10 \mathrm{~min}$ and its electrical conductivity was also recorded (EC2). MSI was calculated as in Eq. (2):

$$
\mathrm{MSI}=[1-(\mathrm{EC} 1 / \mathrm{EC} 2)] \times 100
$$

The relative water content (RWC) was determined by recording the turgid of $0.5 \mathrm{~g}$ of fresh leaf samples by keeping in water of four hours. After 4 hours the samples were taken out of water and well dried quickly with filter paper and immediately weighted for obtaining the fully turgid weight. The samples are oven dried at $65 \pm 5^{\circ} \mathrm{C}$ in hot air oven till constant weight to determined dry weight [41]. The RWC was calculated using Eq. (3):

$$
\text { RWC }=\frac{\text { Fresh wt }- \text { dry wt }}{\text { Turgid wt }- \text { dry wt }} \times 100
$$

The extractable $\mathrm{Pb}$ in the shoot was determined after digestion in di-acid (nitric acid and perchloric acid) [42] followed by measurement on an atomic absorption spectrophotometer (AAS) (Hitachi polarized Zeeman Z-8200; Hitachi, Japan).

\subsection{Statistical analysis}

The obtained data was statically analyzed used computerbased software Statistix 8.1 ${ }^{\circledR}[43]$ and Microsoft Excel $2016^{\circledR}$. Influence of organic amendments on growth and $\mathrm{Pb}$ uptake of spinach grown in lead-contaminated soil were analyzed by the analysis of variance (ANOVA). The LSD test was applied for treatments means comparison.

\section{RESULTS}

\subsection{Growth responses}

\subsubsection{Shoot length}

Results revealed that $\mathrm{Pb}$ treatments (500 and $1000 \mathrm{mg} \mathrm{kg}^{-1}$ ) decreased shoot length $(\mathrm{cm})$ of spinach crop as compared to control. At $1000 \mathrm{mg} \mathrm{kg}^{-1} \mathrm{~Pb}$ caused significant reduction $(p=0.001)$ in shoot length than control. However, the application of $\mathrm{BC}$ and compost increased shoot length in control and $\mathrm{Pb}$-spiked soil. The application of compost enhanced the shoot length by 25 and $35.7 \%$ at 500 and 1000 $\mathrm{mg} \mathrm{kg}^{-1} \mathrm{~Pb}$ contamination respectively over respective control. While biochar application enhanced the shoot length by 22.7 and $34.8 \%$ at 500 and $1000 \mathrm{mg} \mathrm{kg}^{-1} \mathrm{~Pb}$ contamination level respectively. The maximum shoot length was observed in control treatment where $\mathrm{Pb}$ contamination was not present with the application $1 \%$ compost. Both amendments were proved good for enhancing shoot length in $\mathrm{Pb}$-contaminated soil (Figure 1).

\subsubsection{Root length}

Results showed that $\mathrm{Pb}$ treatments at $\left(500\right.$ and $1000 \mathrm{mg} \mathrm{kg}^{-}$ $\left.{ }^{1}\right)$ decreased root length of spinach crop grown in $\mathrm{Pb}$-spiked soil as compared to control. However, $1000 \mathrm{mg} \mathrm{kg}^{-1}$ solution had significantly $(\mathrm{p}=0.001)$ reduced root length under $\mathrm{Pb}$ stress. The application of compost and biochar increased the root length in control and $\mathrm{Pb}$-contaminated soil. The compost application enhanced the root length by 29.8 and $26 \%$ at 500 and $1000 \mathrm{mg} \mathrm{kg}^{-1} \mathrm{~Pb}$ contamination respectively over the respective control. While application of biochar enhanced the root length by 22.7 and $21.3 \%$ at 500 and $1000 \mathrm{mg} \mathrm{kg}^{-1} \mathrm{~Pb}$ contamination level respectively over respective control. The maximum root length was observed in control treatment where $\mathrm{Pb}$ contamination was not present with application of $1 \%$ compost. Both biochar and compost were proved good for enhancing the root length in $\mathrm{Pb}$-contaminated soil (Figure 2).

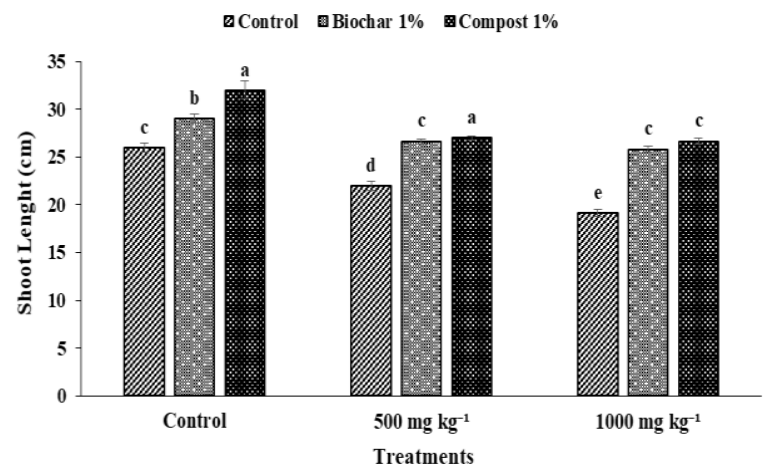

Figure 1. Effect of biochar and compost on shoot length of spinach grown in $\mathrm{Pb}$-contaminated soil

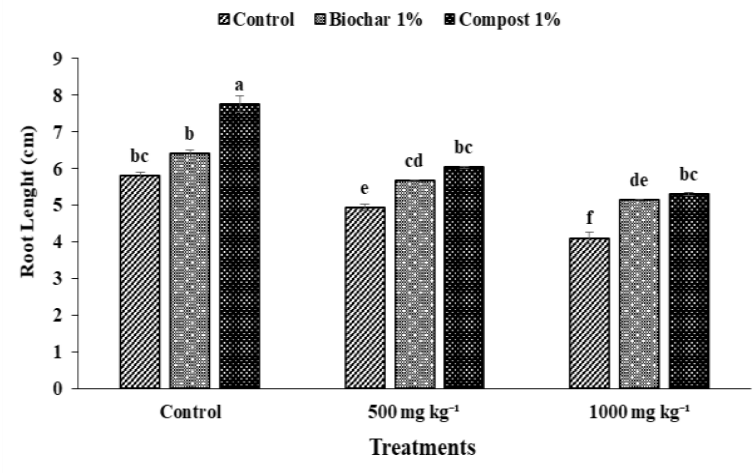

Figure 2. Effect of biochar and compost on root length of spinach grown in $\mathrm{Pb}$-contaminated soil

Table 1. Basic physiochemical properties of soil

\begin{tabular}{|c|c|c|c|c|c|c|c|c|c|c|}
\hline $\begin{array}{c}\text { Organic } \\
\text { Matter } \\
\left(\mathrm{g} \mathrm{Kg}^{-1}\right)\end{array}$ & $\mathrm{pH}$ & $\begin{array}{c}\mathrm{ECe} \\
\left(\mathrm{dSm}^{-1}\right)\end{array}$ & $\begin{array}{c}\text { Saturation } \\
(\%)\end{array}$ & $\begin{array}{c}\mathrm{CEC}(\mathrm{Cmolc} \\
\left.\mathrm{kg}^{-1}\right)\end{array}$ & $\begin{array}{c}\text { Total Nitrogen } \\
(\%)\end{array}$ & $\begin{array}{c}\text { Sand } \\
(\%)\end{array}$ & $\begin{array}{c}\text { Silt } \\
(\%)\end{array}$ & $\begin{array}{c}\text { Clay } \\
(\%)\end{array}$ & $\begin{array}{c}\text { Textural } \\
\mathrm{Class}\end{array}$ & $\begin{array}{c}\text { Extractable Pb (mg } \\
\left.\mathrm{kg}^{-1}\right)\end{array}$ \\
\hline$\left(\mathrm{mg} \mathrm{kg}^{-1}\right)$ & 7.2 & 1.5 & 29.8 & 1.41 & 0.0047 & 62.5 & 13.0 & 24.5 & $\begin{array}{c}\text { Sandy clay } \\
\text { loam }\end{array}$ & ND* \\
\hline
\end{tabular}

$\mathrm{ND}=$ Not Detectable. 


\subsubsection{Shoot dry weight}

Data showed that $\mathrm{Pb}$ treatment had significantly $(\mathrm{P}<0.05)$ reduced the shoot dry weights of the spinach crop by 32.8 and $33.9 \%$ at both treatments 500 and $1000 \mathrm{mg} \mathrm{kg}^{-1}$ respectively as compared to control. However, the application of compost and biochar increased shoot dry weight in control and $\mathrm{Pb}$ contaminated soil. The enhancement in the shoot dry weight was pronounced in response to compost as compared biochar. The compost application increased the shoot dry weight by 48.8 and $26.4 \%$, while BC increased the shoot dry weight by 40.7 and $21.5 \%$ at 500 and $1000 \mathrm{mg} \mathrm{kg}^{-1}$ of $\mathrm{Pb}$-contamination level respectively over respective control (Figure 3 ).

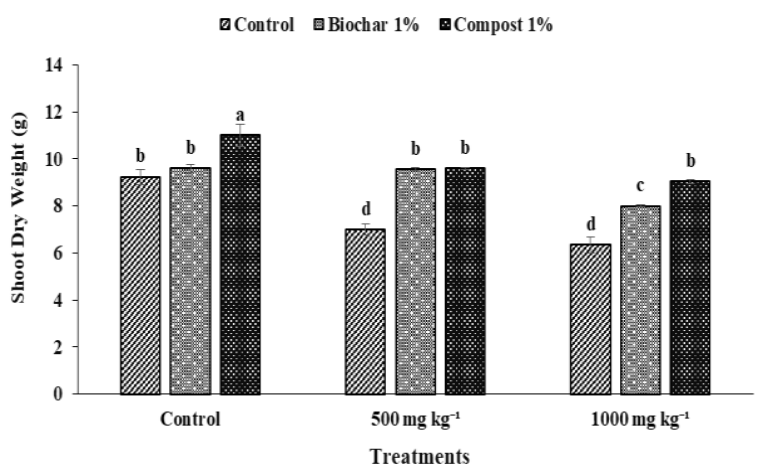

Figure 3. Effect of biochar and compost on shoot dry weight of spinach grown in $\mathrm{Pb}$-contaminated soil

\subsubsection{Root dry weight}

Results in Figure 4 revealed that $\mathrm{Pb}$ reduced the root dry weight but application of biochar and compost significantly enhanced the root dry weight as compared to control. The root dry weight was decreased with increasing the level of $\mathrm{Pb}$ contamination. There was 36.4 and $42.2 \%$ reduction shown in root dry weight of spinach grown at 500 and $1000 \mathrm{mg} \mathrm{Pb} \mathrm{kg}^{-1}$ soil respectively as compared to control. However, the application of compost and biochar increased root dry weight in control and $\mathrm{Pb}$-contaminated soil. The increment in the root dry weight was pronounced in response to compost as compared biochar. The compost application enhanced the root dry weight by 48.1 and $40.6 \%$, while the application of biochar enhanced the root dry weight by 33.2 and $20.6 \%$ at 500 and $1000 \mathrm{mg} \mathrm{kg}^{-1} \mathrm{~Pb}$-contamination level respectively over respective control.

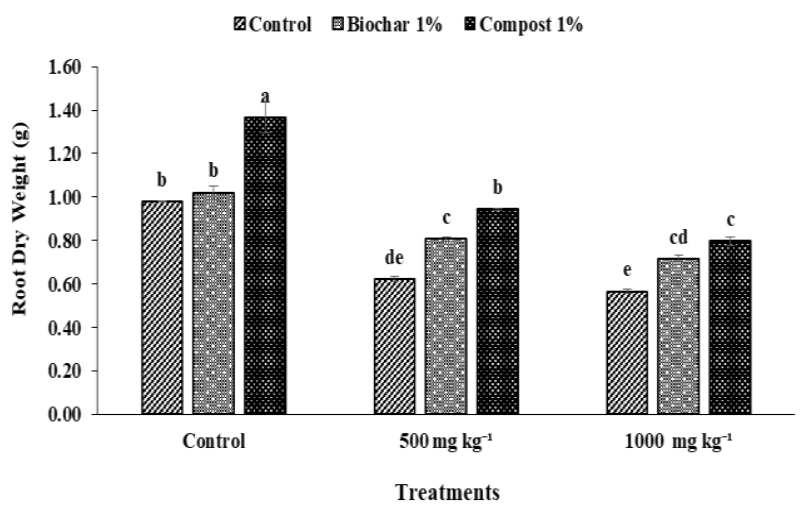

Figure 4. Effect of biochar and compost on root dry weight of spinach grown in $\mathrm{Pb}$-contaminated soil

\subsection{Physiological responses}

\subsubsection{Total chlorophyll contents}

The $\mathrm{Pb}$ significantly $(\mathrm{P}<0.05)$ decreased the total chlorophyll contents of spinach crop by 18.8 and $32.6 \%$ grown in soil contaminated with 500 and $1000 \mathrm{mg} \mathrm{Pb} \mathrm{kg}^{-1}$ soil, respectively as compared to control. The application of biochar and compost increased the chlorophyll contents under $\mathrm{Pb}$-stressed and non-stressed condition. It was observed that maximum increased in the chlorophyll contents was found in the treatment involving the sole application of compost and biochar, where 8.2 and $4.6 \%$ increased were observed in the chlorophyll contents as compared with control ( $\mathrm{No}-\mathrm{Pb}$-stress). Application of biochar increased 21 and $31.2 \%$ chlorophyll contents in 500 and $1000 \mathrm{mg} \mathrm{Pb} \mathrm{kg}^{-1}$ soil respectively. While the application of compost increased chlorophyll contents by 22 and $32.5 \%$ in a soil contaminated with 500 and $1000 \mathrm{mg} \mathrm{Pb}$ $\mathrm{kg}^{-1}$ soil, respectively as compared to their respective control (Figure 5).

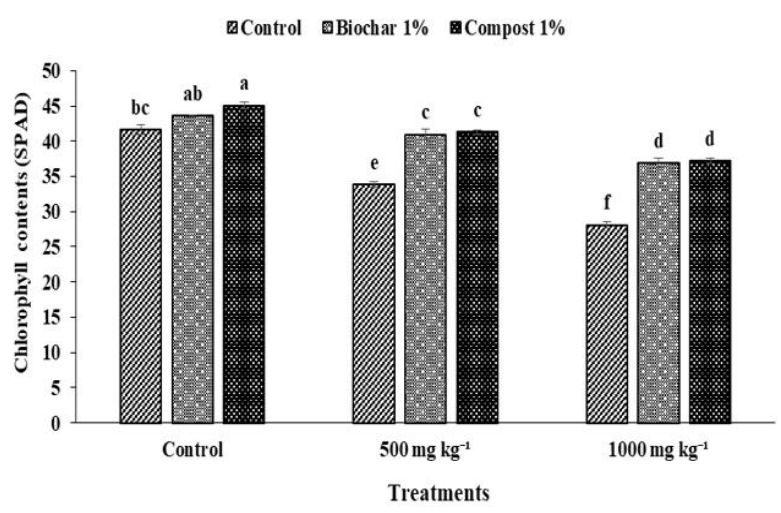

Figure 5. Effect of biochar and compost on total chlorophyll contents of spinach grown in $\mathrm{Pb}$-contaminated soil

\subsubsection{Relative water content}

The relative water contents of spinach crop significantly decreased by 32.7 and $38.1 \%$ grown in soil contaminated with 500 and $1000 \mathrm{mg} \mathrm{Pb} \mathrm{kg}^{-1}$ soil, respectively as compared to treatment received no $\mathrm{Pb}$ and organic amendments (Figure 6). The application of compost and biochar is to enhance the RWC as compared to the control and Pb-stressed condition. Biochar enhanced the RWC and was more pronounced in response to compost as compared to the respective control. At 500 and $1000 \mathrm{mg} \mathrm{kg}^{-1}$, the application of biochar enhanced the RWC by 44.6 and $37 \%$ and compost enhanced by 34.3 and $32.9 \%$ as compared to the respective control.

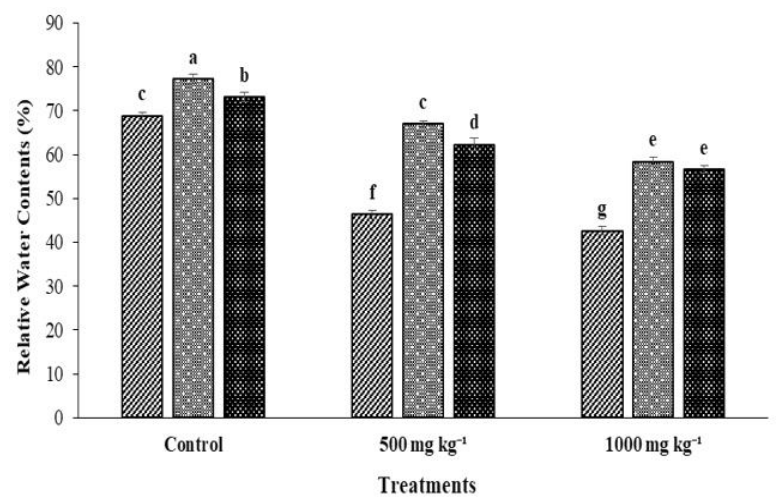

Figure 6. Effect of biochar and compost on relative water contents of spinach grown in $\mathrm{Pb}$-contaminated soil 


\subsubsection{Membrane stability index}

The membrane stability index (MSI) of spinach (Figure 7) presented was significantly affected by soil $\mathrm{Pb}$ contamination and applied amendments. The MSI was decreased with increasing level of $\mathrm{Pb}$ contamination. There was 16.5 and $26.1 \%$ reduction in MSI of spinach grown at $\mathrm{Pb}$ contamination of 500 and $1000 \mathrm{mg} \mathrm{kg}^{-1}$ respectively as compared to control. However, the application of biochar and compost increased MSI in control and Pb-spiked soil. The enhancement in MSI was more pronounced in response to biochar as compared to compost. The application of biochar enhanced the MSI by 18.8 and $27.1 \%$ at 500 and $1000 \mathrm{mg} \mathrm{kg}^{-1} \mathrm{~Pb}$ contamination respectively over respective control. While compost application enhanced the MSI by 17.7 and $23.5 \%$ at 500 and $1000 \mathrm{mg}$ kg-1 $\mathrm{Pb}$ contamination level respectively over respective control. The maximum MSI was observed in control treatment where $\mathrm{Pb}$ contamination was not present with the application $1 \%$ green waste biochar. Both amendments were proved good for enhancing MSI in $\mathrm{Pb}$ contaminated soil.

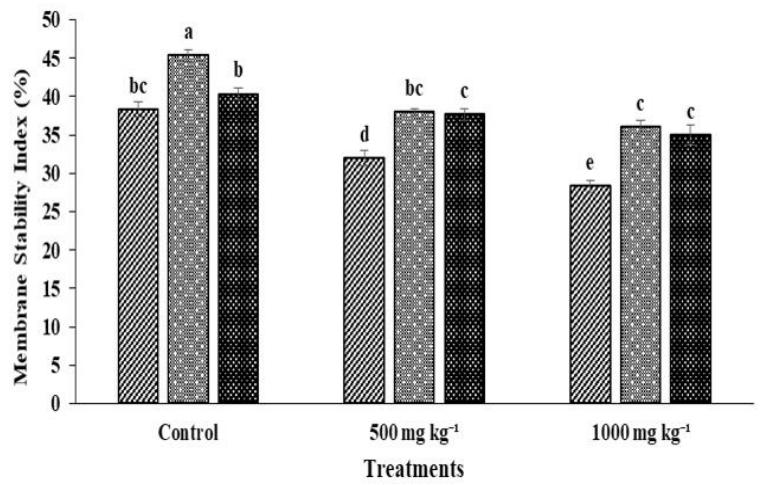

Figure 7. Effect of biochar and compost on membrane stability index of spinach grown in $\mathrm{Pb}$ contaminated soil

3.2.4 AB-DTPA extractable $\mathrm{Pb}$ concentration in postexperiment soil

The AB-DTPA extractable $\mathrm{Pb}$ concentration in postharvesting soil (Figure 9) presented, there was a significant increase in soil extractable $\mathrm{Pb}$ due to application of $\mathrm{Pb}$ found with maximum concentration in soil contaminated with 1000 $\mathrm{mg} \mathrm{kg}^{-1}$ soil. The extractable $\mathrm{Pb}$ was greatly influenced with application of organic amendments. The application of biochar significantly $(\mathrm{P} \leq 0.05)$ decreased the extractable $\mathrm{Pb}$ by 31.4 and $29.8 \%$, respectively in soil received 500 and $1000 \mathrm{mg} \mathrm{Pb}$ $\mathrm{kg}^{-1}$ soil. However, compost application decreased the extractable $\mathrm{Pb}$ by 27.38 and $22.2 \%$, respectively in soil received 500 and $1000 \mathrm{mg} \mathrm{Pb} \mathrm{kg}^{-1}$ soil as compared to its respective control.

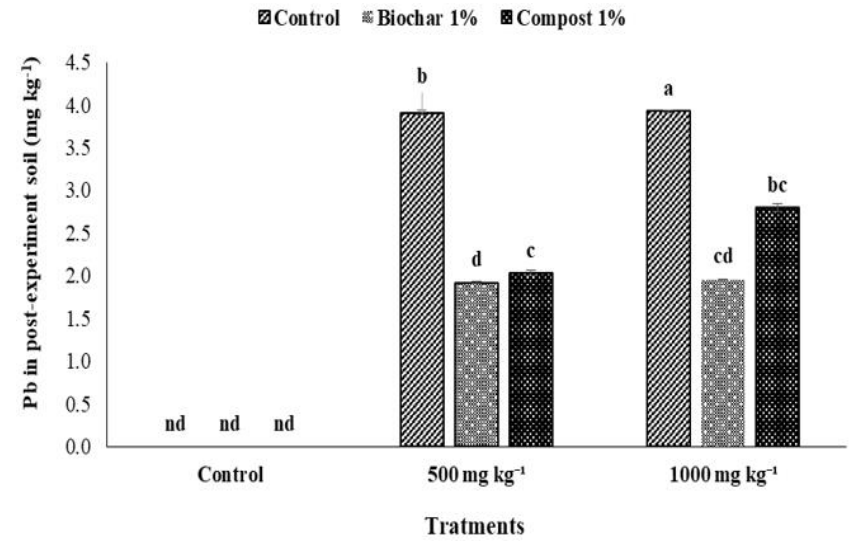

Figure 8. Effect of biochar and compost on $\mathrm{Pb}$ concentration in shoot of spinach grown in $\mathrm{Pb}$-contaminated soil

\subsection{Concentration of $\mathbf{P b}$}

\subsubsection{Lead concentration in shoot of Spinach}

Figure 8 illustrates that the $\mathrm{Pb}$ concentration in the shoot of 45 days' seedlings of spinach grown in $\mathrm{Pb}$-contaminated soil (500 and $1000 \mathrm{mg} \mathrm{Pb} \mathrm{kg}^{-1}$ soil). The results revealed that the $\mathrm{Pb}$-concentration in shoot of spinach crop was significantly $(\mathrm{P}<0.05)$ influenced by $\mathrm{Pb}$-contamination and applied amendments (Biochar and compost $1 \% \mathrm{~W} / \mathrm{W}$ ). The $\mathrm{Pb}-$ contents present in the shoot were 23.7 and $27.6 \mathrm{mg} \mathrm{kg}^{-1}$ spinach grown at 500 and $1000 \mathrm{mg} \mathrm{Pb} \mathrm{kg-1} \mathrm{soil.} \mathrm{While} \mathrm{the} \mathrm{Pb}$ concentration in shoot decreased up to 56.3 and $41.55 \%$ respectively by addition of biochar at 500 and $1000 \mathrm{mg} \mathrm{kg}^{-1}$ $\mathrm{Pb}$-stress. However, addition of compost decreased the $\mathrm{Pb}$ uptake of spinach crop by 38 and $29.8 \%$ respectively as compared to the respective control.

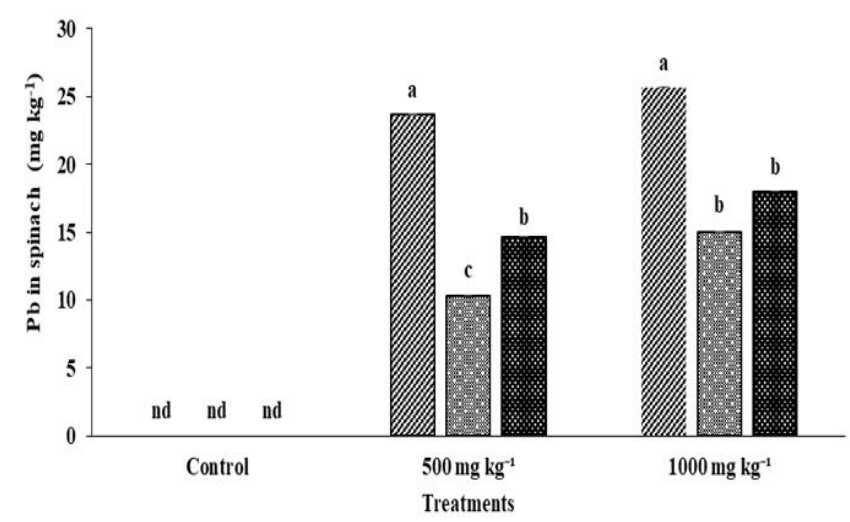

Figure 9. Effect of biochar and compost on $\mathrm{Pb}$ concentration in post-experiment soil

Table 2. Characteristic of poultry manure compost

\begin{tabular}{c|c|c} 
Compost Characteristics & \multicolumn{1}{c}{ Units } & Value \\
\hline $\mathrm{ECe}$ & $\mathrm{dS} \mathrm{m}^{-1}$ & 38 \\
$\mathrm{pH}$ & - & 8.10 \\
$\mathrm{Na}^{+}$ & $\mathrm{mg} \mathrm{kg}^{-1}$ & 687 \\
$\mathrm{~N}$ & $\%$ & 4.36 \\
$\mathrm{P}$ & $\%$ & 3 \\
$\mathrm{~K}$ & $\%$ & 4 \\
Organic matter & $\%$ & 70.55 \\
$\mathrm{AB}-\mathrm{DTPA}$ Extractable $\mathrm{Pb}$ & $\mathrm{mg} \mathrm{kg}^{-1}$ & $\mathrm{ND}^{*}$ \\
\hline $\mathrm{ND}=$ Not Detectable
\end{tabular}


Table 3. Characteristic of green waste feedstock biochar produced at $350^{\circ} \mathrm{C}$ pyrolytic temperature

\begin{tabular}{|c|c|c|}
\hline Biochar Characteristics & Units & Greenwaste Biochar $350{ }^{\circ} \mathrm{C}$ \\
\hline \multicolumn{3}{|l|}{ Elemental characteristics } \\
\hline $\mathrm{C}$ & $\%$ & $39.30 \pm .2 .4$ \\
\hline $\mathrm{H}$ & $\%$ & $03.96+0.4$ \\
\hline $\mathrm{O}$ & $\%$ & $19.10 \pm .1 .8$ \\
\hline $\mathrm{N}$ & $\%$ & $1.47 \pm .0 .1$ \\
\hline$S$ & $\mathrm{gkg}^{-1}$ & $8.65 \pm .1 .3$ \\
\hline $\mathrm{Pb}$ & $\begin{array}{l}\mathrm{gng} \\
\mathrm{mg} \mathrm{kg}^{-1}\end{array}$ & $\mathrm{ND}^{*}$ \\
\hline \multicolumn{3}{|l|}{ Molar ratios } \\
\hline $\mathrm{H}: \mathrm{C}$ & & $1.22 . \pm .0 .20$ \\
\hline $\mathrm{O}: \mathrm{C}$ & & $0.36 . \pm .0 .04$ \\
\hline \multicolumn{3}{|c|}{ Physicochemical characteristics } \\
\hline Surface area & $\mathrm{m}^{2} \mathrm{~g}^{-1}$ & $23.80 \pm 2.8$ \\
\hline CEC* & Cmolc kg-1 & $43.70 \pm 5.2$ \\
\hline $\mathrm{pH}$ & & $7.91 \pm 16$ \\
\hline \multicolumn{3}{|l|}{ Proximate Composition } \\
\hline Ash Content & $\%$ & 27.23 \\
\hline Fixed Carbon & $\%$ & 24.62 \\
\hline Volatile matter & $\%$ & 41.27 \\
\hline Yield & $\%$ & 40.31 \\
\hline \multicolumn{3}{|c|}{ O-Containing functional groups } \\
\hline Carboxylic & Meq $g^{-1}$ & 0.121 \\
\hline Lactonic & Meq $\mathrm{g}^{-1}$ & 0.130 . \\
\hline Phenolic & Meq $\mathrm{g}^{-1}$ & 0.131 \\
\hline
\end{tabular}

$\mathrm{ND}=$ Not Detectable

\section{DISCUSSION}

Lead inhibits plant growth, physiological, and biochemical parameters and its toxicity increases by increasing the $\mathrm{Pb}$ concentration in soil. Different approaches are using to ameliorate the $\mathrm{Pb}$ toxicity to plants such as physical, chemical and biological, while the use of different organic amendment has more advantages over the other approaches i.e. efficient, cheap, socially acceptable, environment friendly and used as an in-situ. This study was conducted to investigate the effects of various types of organic amendments (BC and Compost $1 \%$ $\mathrm{w} / \mathrm{w}$ ), on growth development, physiology, and $\mathrm{Pb}$-uptake in spinach crop that exposed to vary levels of $\mathrm{Pb}$. Results revealed that increasing concentration of $\mathrm{Pb}$ reduced the shoot and root length, dry weights of spinach crop. Also, the MSI, total chlorophyll contents and RWC were adversely reduced. Other visual symptoms showed by plants in case of Pb-toxicity stunted of growth, chlorosis etc. These results are correlate with previous findings that the increasing $\mathrm{Pb}$ concentration in soil causing toxicity to spinach crop as that is responsible for the of growth and physiological parameters [8, 44]. Comparatively, significant enhancement was observed in the growth development of the spinach crop like root and shoot length, dry weights (Figures 1, 2, 3, and 4) and physiological parameters i.e. total chlorophyll contents, MSI and RWC (Figures 5, 6, and 7) of spinach grown under $\mathrm{Pb}$-stress by application organic amendments. The results are also in covenant with the results of McBride [45]. Compost application improved the soil health, maintained the soil moister contents and nutrients supplier to plants and were recorded in this study. The compost tended to contribute in increasing of the plant's biomasses, and physiological attributes. Correspondingly, the results were also conveyed by Irshad, who witnessed that the growth of plant showed positive change in heavy metals contaminated soil amended by compost [46]. Biochar improved the soil physical properties such as decreased soil strength as well as increased water holding capacity that would possibly improve the crop growth [47]. Furthermore, BC increases soil fertility level, in addition to soil organic matter (SOM) contents hence increasing the growth of plant [48]. Thus, the obtained results, depicted that these organic amendments were able to increase the spinach growth.

The $\mathrm{BC}$ and Compost had substantial impacted on $\mathrm{Pb}$ stabilization in soil (Figure 9). The obtained results revealed, significant reducing in $\mathrm{Pb}$-uptake of spinach crop grown in biochar and compost amended soil under $\mathrm{Pb}$ stress. Organic supplements like $\mathrm{BC}$ and compost can also improve the chemical and biological properties of the soils, particularly soil total organic contents (TOC) and CEC which might be considered an important reason for the reduction of total available $\mathrm{Pb}$ concentration in soil ecosystem. The results are also parallel to the findings of Uchimiya and Bian. They noted a high increase in the soil CEC and organic carbon contents with high surface area that responded significant low available concentration of heavy metals due to the sorption and adsorption mechanisms of the organic amendments by charged sites. Stabilization of $\mathrm{Pb}$ increased with the organic amendments that conformed a positive role for the mitigation of $\mathrm{Pb}$-stresses through reduction of AB-DTPA extractable $\mathrm{Pb}$ in soil $[49,50]$. Karami described that $\mathrm{BC}$ and compost application can stabilize different heavy metals by a number of process of adsorption, co-precipitation or binding with the charged sites and thus decreased their availability in soil [51]. The $\mathrm{BC}$ with high CEC, more oxygen and hydrogen bonds comprising functional groups showing greater heavy metal immobilization in soil environment [52]. Biochar characteristics like CEC, surface area, $\mathrm{pH}$, presence of oxygen consisting functional groups and organic carbon content are playing an important role for immobilization of heavy metals in soil [49]. Results (Figure 9) obtained from experiment revealed that $\mathrm{Pb}$ translocation factor was significantly affected 
by organic amendments. Addition of $\mathrm{BC}$ at rate of $1 \%$ in soil significantly decreased $\mathrm{Pb}$ translocation factor as compared to compost. Biochar application to soil improves physical and chemical as well as the biological properties which turn results in reduction of available $\mathrm{Pb}$ concentration. Furthermore, investigated that $\mathrm{BC}$ itself has greater ability for metals sorption from soil due to having oxygen containing functional groups, precipitation of heavy metal with carbonate and phosphate compounds present at high concentration on biochar and also by means of ion exchange mechanisms in consequence of biochar high CEC $[49,50]$. Thus, organic amendments have frequently been observed to tolerate huge amount of metals and to enhance the production of plant under heavy metal stress condition.

\section{CONSULSION}

In the present study, organic amendments (biochar and compost) were used to improve the growth of spinach in the presence of varying levels of $\mathrm{Pb}$. The results depicted that presence of $\mathrm{Pb}$ in the soil adversely affected the growth of spinach. It was concluded that organic amendments reduce the $\mathrm{Pb}$ toxicity as well as increased the growth and physiological attributes of spinach. However, these results should be continued in future experiments. Moreover, the economic feasibility and farmer's suitability for organic amendments should be studied.

\section{ACKNOWLEDGMENT}

The authors are very thankful to Institute of Soil and Environmental Sciences (ISES), University of Agricultural Faisalabad, Pakistan for providing the research facility and experimental area. They are also grateful to the Soil and Water Testing laboratory Chiniot, Institut Superieur D agriculture, Lille catholic France and United Nation University, Bonn Germany for their technical support.

\section{REFERENCES}

[1] Wan, X., Lei, M., Chen, T. (2016). Cost-benefit calculation of phytoremediation technology for heavymetal-contaminated soil. Science of the Total Environment, 563: 796-802. https://doi.org/10.1016/j.scitotenv.2015.12.080

[2] Ali, H., Khan, E., Sajad, M.A. (2013). Phytoremediation of heavy metals-concepts and applications. Chemosphere, $\quad 91(7)$ : $869-881$. https://doi.org/10.1016/j.chemosphere.2013.01.075

[3] Ullah, A., Mushtaq, H., Ali, H., Munis, M.F.H., Javed, M.T., Chaudhary, H.J. (2015). Diazotrophs-assisted phytoremediation of heavy metals: A novel approach. Environmental Science and Pollution Research, 22(4): 2505-2514. https://doi.org/10.1007/s1 1356-014-3699-5

[4] Park, J.D. (2010). Heavy metal poisoning. Hanyang. Med. Rev. 30: 319-325.

[5] Iqbal, M.P. (2012). Lead pollution-a risk factor for cardiovascular disease in Asian developing countries. Pakistan Journal of Pharmaceutical Sciences, 25(1): 289 294. https://doi.org/10.1254/jphs.11177SC

[6] Järup, L. (2003). Hazards of heavy metal contamination.
British Medical Bulletin, 68(1): 167-182. https://doi.org/10.1254/jphs.11177SC

[7] Luo, S., Xu, T., Chen, L., Chen, J., Rao, C., Xiao, X., Wan, Y., Zeng, G., Long, F., Liu, C., Liu. Y. (2012). Endophyte-assisted promotion of biomass production and metal-uptake of energy crop sweet sorghum by plantgrowth-promoting endophyte Bacillus sp. SLS18. Applied Microbiology and Biotechnology, 93(4): 17451753. https://doi.org/10.1007/s00253-011-3483-0

[8] Alia, N., Sardar, K., Said, M., Salma, K., Sadia, A., Sadaf, S., Toqeer, A., Miklas, S. (2015). Toxicity and bioaccumulation of heavy metals in spinach (Spinacia oleracea) grown in a controlled environment. International Journal of Environmental Research and Public Health, 12(7): 7400-7416. https://doi.org/10.3390/ijerph120707400

[9] Talanova, V.V., Titov, A.F., Boeva, N.P. (2000). Effect of increasing concentrations of lead and cadmium on cucumber seedlings. Biologia Plantarum, 43(3): 441-444. https://doi.org/10.1023/A:1026735603890

[10] Gupta, D.K., Huang, H.G., Corpas, F.J. (2013). Lead tolerance in plants: Strategies for phytoremediation. Environmental Science and Pollution Research, 20(4): 2150-2161. https://doi.org/10.1007/s11356-013-1485-4

[11] Odum, H.T., Brown, M.T., Brandt-Williams, S. (2000). Handbook of energy evaluation. Center for environmental policy.

[12] Cheng, H., Hu, Y. (2010). Lead (Pb) isotopic fingerprinting and its applications in lead pollution studies in China: A review. Environmental pollution, 158(5):

1134-1146. https://doi.org/10.1016/j.envpol.2009.12.028

[13] Bhattacharyya, P., Chakrabarti, K., Chakraborty, A., Tripathy, S., Powell, M.A. (2008). Fractionation and bioavailability of $\mathrm{Pb}$ in municipal solid waste compost and $\mathrm{Pb}$ uptake by rice straw and grain under submerged condition in amended soil. Geosciences Journal, 12(1): 41-45. https://doi.org/10.1007/s12303-008-0006-9

[14] Dauvin, J.C. (2008). Effects of heavy metal contamination on the macrobenthic fauna in estuaries: the case of the Seine estuary. Marine Pollution Bulletin, 57(1-5): 160-169. https://doi.org/10.1016/j.marpolbul.2007.10.012

[15] Lombardi, P.E., Peri, S.I., Guerrero, N.R.V. (2010). ALA-D and ALA-D reactivated as biomarkers of lead contamination in the fish Prochilodus lineatus. Ecotoxicology and Environmental Safety, 73(7): 17041711. https://doi.org/10.1016/j.ecoenv.2010.06.005

[16] Lam, T.V., Agovino, P., Niu, X., Roché, L. (2007). Linkage study of cancer risk among lead-exposed workers in New Jersey. Science of the Total Environment, 372(2-3): 455-462. https://doi.org/10.1016/j.scitotenv.2006.10.018

[17] Watt, G.C.M., Britton, A., Gilmour, H.G., Moore, M.R., Murray, G.D., Robertson, S.J. (2000). Public health implications of new guidelines for lead in drinking water: a case study in an area with historically high water lead levels. Food and Chemical Toxicology, 38: S73-S79. https://doi.org/10.1016/s0278-6915(99)00137-4

[18] FAO. (2008). An introduction to the basic concepts of food security. FAO, Rome, Italy. http://www.fao.org/docrep/013/a1936e/a1936e00.pdf.

[19] Sharma, A., Nagpal, A.K. (2018). Soil amendments: A tool to reduce heavy metal uptake in crops for production 
of safe food. Reviews in Environmental Science and Bio/Technology, 17(1): 187-203. https://doi.org/10.1007/s11157-017-9451-0

[20] Bolan, N.S., Duraisamy, V.P. (2003). Role of inorganic and organic soil amendments on immobilisation and phytoavailability of heavy metals: a review involving specific case studies. Australian Journal of Soil Research, 41(3): 533-555.

[21] Naidu, R., Semple, K.T., Megharaj, M., Juhasz, A.L., Bolan, N.S., Gupta, S.K., Clothier, B., Schulin, R. (2008). Bioavailability: Definition, assessment and implications for risk assessment. Developments in Soil Science, 32: 39-51. https://doi.org/10.1016/S0166-2481(07)32003-5

[22] Basta, N.T., McGowen, S.L. (2004). Evaluation of chemical immobilization treatments for reducing heavy metal transport in a smelter-contaminated soil. Environmental Pollution, 127(1): 73-82. https://doi.org/10.1016/S0269-7491(03)00250-1

[23] Mullainathan, L., Arulbalachandran, D., Lakshmanan, G. M.A., Velu, S. (2007). Phytoremediation: metallophytes an effective tool to remove soil toxic metal. Plant Archives, 7(1): 19-23. https://doi.org/10.1007/s11104006-9181-5

[24] Lee, W.J., Shih, S.I., Chang, C.Y., Lai, Y.C., Wang, L.C., Chang-Chien, G.P. (2008). Thermal treatment of polychlorinated dibenzo-p-dioxins and dibenzofurans from contaminated soils. Journal of Hazardous Materials, 160(1):

220-227. https://doi.org/10.1016/j.jhazmat.2008.02.113

[25] Oste, L.A., Lexmond, T.M., Van Riemsdijk, W.H. (2002). Metal immobilization in soils using synthetic zeolites. Journal of Environmental Quality, 31(3): 813821. https://doi.org/10.2134/jeq2002.0813

[26] Shahid, M., Austruy, A., Echevarria, G., Arshad, M., Sanaullah, M., Aslam, M., Nadeem, M., Nasim, W. Dumat, C. (2014). EDTA-enhanced phytoremediation of heavy metals: A review. Soil and Sediment Contamination: An International Journal, 23(4): 389-416. https://doi.org/10.1080/15320383.2014.831029

[27] Woolf, D., Amonette, J.E., Street-Perrott, F.A., Lehmann, J., Joseph, S. (2010). Sustainable biochar to mitigate global climate change. Nature Communications, 1(1): 19. https://doi.org/10.1038/ncomms 1053

[28] Zhang, X., Wang, H., He, L., Lu, K., Sarmah, A., Li, J., Bolan, N.S., Pei, J., Huang, H. (2013). Using biochar for remediation of soils contaminated with heavy metals and organic pollutants. Environmental Science and Pollution Research, 20(12): 8472-8483. https://doi.org/10.1007/s11356-013-1659-0

[29] Jiang, J., Xu, R.K., Jiang, T.Y., Li, Z. (2012). Immobilization of $\mathrm{Cu}$ (II), $\mathrm{Pb}$ (II) and $\mathrm{Cd}$ (II) by the addition of rice straw derived biochar to a simulated polluted Ultisol. Journal of Hazardous Materials, 229: 145-150. https://doi.org/10.1016/j.jhazmat.2012.05.086

[30] Beesley, L., Moreno-Jiménez, E., Gomez-Eyles, J.L. (2010). Effects of biochar and greenwaste compost amendments on mobility, bioavailability and toxicity of inorganic and organic contaminants in a multi-element polluted soil. Environmental Pollution, 158(6): 22822287. https://doi.org/10.1016/j.envpol.2009.07.021

[31] Park, J.H., Choppala, G.K., Bolan, N.S., Chung, J.W., Chuasavathi, T. (2011). Biochar reduces the bioavailability and phytotoxicity of heavy metals. Plant and Soil, 348(1-2): 439. https://doi.org/10.1007/s11104- 011-0948-y

[32] Tang, J., Zhu, W., Kookana, R., Katayama, A. (2013). Characteristics of biochar and its application in remediation of contaminated soil. Journal of Bioscience and Bioengineering, 116(6): 653-659. https://doi.org/10.1016/j.jbiosc.2013.05.035

[33] Castaldi, P., Santona, L., Melis, P. (2005). Heavy metal immobilization by chemical amendments in a polluted soil and influence on white lupin growth. Chemosphere, 60(3): 365-371. https://doi.org/10.1016/j.chemosphere.2004.11.098

[34] O'Dell, R., Silk, W., Green, P., Claassen, V. (2007). Compost amendment of $\mathrm{Cu}-\mathrm{Zn}$ minespoil reduces toxic bioavailable heavy metal concentrations and promotes establishment and biomass production of Bromus carinatus (Hook and Arn.). Environmental Pollution, 148(1):

115-124.

https://doi.org/10.1016/j.envpol.2006.10.037

[35] Kumar, V., Chopra, A.K., Srivastava, S. (2016). Assessment of heavy metals in spinach (Spinacia oleracea L.) grown in sewage sludge-amended soil. Communications in Soil Science and Plant Analysis, 47(2):

221-236. https://doi.org/10.1080/00103624.2015.1122799

[36] Yadav, R.K., Goyal, B., Sharma, R.K., Dubey, S.K., Minhas, P.S. (2002). Post-irrigation impact of domestic sewage effluent on composition of soils, crops and ground water - a case study. Environment International, 28(6): 481-486. https://doi.org/10.1016/S01604120(02)00070-3.

[37] Tandi, N.K., Nyamangara, J., Bangira, C. (2004). Environmental and potential health effects of growing leafy vegetables on soil irrigated using sewage sludge and effluent: $\mathrm{A}$ case of $\mathrm{Zn}$ and $\mathrm{Cu}$. Journal of Environmental Science and Health, Part B, 39(3): 461471. https://doi.org/10.1081/PFC-120035930

[38] Abu-Hamdeh, N.H. (2004). The effect of tillage treatments on soil water holding capacity and on soil physical properties. In Conserving soil and water for society: sharing solutions. ISCO 13th International Soil Conservation Organization Conference, Brisbane Australia, pp. 1-6.

[39] Markwell, J., Osterman, J.C., Mitchell, J.L. (1995). Calibration of the Minolta SPAD-502 leaf chlorophyll meter. Photosynthesis Research, 46(3): 467-472. https://doi.org/10.1007/BF00032301

[40] Sairam, R.K. (1994). Effects of homobrassinolide application on plant metabolism and grain yield under irrigated and moisture-stress conditions of two wheat varieties. Plant Growth Regulation, 14(2): 173-181. https://doi.org/10.1007/BF00032301

[41] Barrs, H.D., Weatherley, P.E. (1962). A re-examination of the relative turgidity technique for estimating water deficits in leaves. Australian Journal of Biological Sciences, $\quad 15(3)$ : 413-428. https://doi.org/10.1071/bi9620413

[42] Miller, R.O., Kalra, Y. (1998). Nitric-perchloric acid wet digestion in an open vessel. Handbook of Reference Methods for Plant Analysis, 57-61.

[43] Hill, T., Lewicki, P., Lewicki, P. (2006). Statistics: Methods and applications: a comprehensive reference for science, industry, and data mining. Foundations of Anesthesia (Second Edition), StatSoft, Inc. https://doi.org/10.1016/B978-0-323-03707-5.50024-3 
[44] Khan, S., Naz, A., Asim, M., Ahmad, S.S., Yousaf, S., Muhammad, S. (2013). Toxicity and bioaccumulation of heavy metals in spinach seedlings grown on freshly contaminated soil. Pakistan Journal of Botany, 45(supplement 1): 501-508. https://doi.org/10.1080/01904167.2012.759230

[45] McBride, M.B. (1989). Reactions controlling heavy metal solubility in soils. In Advances in Soil Science. Springer, New York, NY, pp. 1-56. https://doi.org/10.1007/978-1-4613-8847-0_1

[46] Irshad, M., Gul, S., Egrinya Eneji, A., Anwar, Z., Ashraf, M. (2014). Extraction of heavy metals from manure and their bioavailability to spinach (Spinacia oleracea L.) after composting. Journal of Plant Nutrition, 37(10): $1661-1675$. https://doi.org/10.1080/01904167.2014.888748

[47] Chan, K.Y., Van Zwieten, L., Meszaros, I., Downie, A., Joseph, S. (2008). Using poultry litter biochars as soil amendments. Soil Research, 46(5): 437-444. https://doi.org/10.1071/SR08036

[48] Schulz, H., Glaser, B. (2012). Effects of biochar compared to organic and inorganic fertilizers on soil quality and plant growth in a greenhouse experiment. Journal of Plant Nutrition and Soil Science, 175(3): 410422. https://doi.org/10.1002/jpln.201100143
[49] Uchimiya, M., Klasson, K.T., Wartelle, L.H., Lima, I.M. (2011). Influence of soil properties on heavy metal sequestration by biochar amendment: 1 . Copper sorption isotherms and the release of cations. Chemosphere, 82(10): 1431-1437. https://doi.org/10.1016/j.chemosphere.2010.11.078

[50] Bian, R., Joseph, S., Cui, L., Pan, G., Li, L., Liu, X., Zhang, A., Rutlidge, H., Wong, S., Chia, C. (2014). A three-year experiment confirms continuous immobilization of cadmium and lead in contaminated paddy field with biochar amendment. Journal of Hazardous Materials, 272: 121-128. https://doi.org/10.1016/j.jhazmat.2014.03.017

[51] Karami, N., Clemente, R., Moreno-Jiménez, E., Lepp, N. W., Beesley, L. (2011). Efficiency of green waste compost and biochar soil amendments for reducing lead and copper mobility and uptake to ryegrass. Journal of Hazardous Materials, 191(1-3): 41-48. https://doi.org/10.1016/j.jhazmat.2011.04.025

[52] Uchimiya, M., Lima, I.M., Klasson, K.T., Wartelle, L.H. (2010). Contaminant immobilization and nutrient release by biochar soil amendment: Roles of natural organic matter. $\quad$ Chemosphere, 80(8): 935-940. https://doi.org/10.1016/j.chemosphere.2010.05.020 